\title{
The Impact of Perceived Corporate Social Responsibility on Purchase Intention: Mediating Role of Brand Attitude and Moderating Role of Generation X \& Y
}

\author{
H.A.D.M. Arachchi \\ Trade \& Investment Policy Department, Ministry of Finance - Sri Lanka \\ slarachchi@yahoo.com \\ Trevor Mendis \\ Senior Management Consultant, Postgraduate Institute of Management, \\ University of Sri Jayewardenepura, Sri Lanka. \\ trevor@pim.sjp.a.lk
}

DOI: http://doi.org/10.4038/sljmuok.v7i3.82

\begin{abstract}
This study, based on the Theory of Planned Behavior (TPB) and the Generation Cohort Theory, attempts to examine the degree of relationship between Perceived corporate social responsibility and Purchase intention, the mediating role of Brand attitude, and the moderating effect of Generation $\mathrm{X}$ and $\mathrm{Y}$ on the relationship between Perceived corporate social responsibility and Purchase intention. The study was carried out on quantitative techniques and followed the deductive approach. The data was collected through a structured questionnaire. Stratified Random Sampling was used to gather data, and the final sample consisted of 392 individual consumers. The data was analyzed using the SPSS and Partial Least Squares-Structural Equation Modelling (PLS-SEM) approaches using Smart PLS 3.0. It was found that Perceived corporate social responsibility related significantly to Purchase intention. Moreover, the relationships between Perceived corporate social responsibility and Brand attitude and Brand Attitude and Purchase Intention were significant. Therefore, Brand attitude was found to be a partial mediator and Generation $\mathrm{X}$ and $\mathrm{Y}$ to be significant moderators of the aforementioned relationship. There were a few limitations in this study which can be examined by future research. One limitation is that the findings of the research was based on one province consisting three districts. Another limitation of this study is that the qualitative and quantitative approaches of this study could have been integrated to yield the mixed method approach through which the findings could have been further clarified, thus enhancing the parameters of the findings. This is the first study empirically investigate of perceived corporate social responsibility on purchase intention: mediating role of brand attitude and moderating role of generation x \& y in the Asian context. And also, important for Marketers in Sri Lanka in deciding their marketing strategies catering to different CSR implementation and purchasing patterns in between the genders.
\end{abstract}

Keywords: Brand Attitude, Generation Cohort Theory, Generation X and Y, Perceived Corporate Social Responsibility, Purchase Intention, Theory of Planned Behavior (TPB)

ORCID of authors: $\quad$ H.A.D.M. Arachchi - (D) https://orcid.org/0000-0002-6363-7637

Copyright: This is an open access article distributed under the Creative Commons Attribution License 4.0, which permits unrestricted use, distribution, and reproduction in any medium, provided the original work is properly cited. 


\section{INTRODUCTION}

Most consumers today are highly conversant with socially and environmentally responsible initiatives and activities, and this can be observed in their purchase intentions (Creyer,1997). Corporate contributions to social causes fall under the umbrella of corporate social responsibility (CSR) programs (David, Kline \& Dai,2005). Corporate philanthropy and social initiatives are now at the heart and soul of the business environment, and they have a large impact on consumer purchase intention (Levy,1999).

There has been much empirical evidence on the positive effect of CSR initiatives on purchase intentions (Sen and Bhattacharya,2001; Mohr \& Webb, 2005; Ko et al., 2008; Gupta and Hodges, 2012; Shen et al., 2012; Phau et al., 2015), while some empirical results have confirmed that the impact of CSR initiatives on purchase intention is very minimal (Wongpitch. et al., 2016). However, Vaaland, Heide, and Grønhaug, (2008) have opined that some consumers are not very interested in a firm's CSR activities because they are more focused on issues that directly benefit themselves. In this case, CSR activities do not relate to company outcomes. Therefore, evidence of perceived CSR activities indicates different levels of relationships with consumer purchase intention and this variance in outcomes has arisen due to consumers' attitudes, including the belief systems of different generations.

Few empirical studies in the past claim and propose that CSR has significant effect when it comes to purchasing decisions, brand choice, recommending the brand to others, or firm value (Boccia \& Sarnacchiaro, 2017; Luffarelli \& Awaysheh, 2018; Salmones, Crespo, \& Bosque, 2005; Sen \& Bhattacharya, 2001; Werther Jr \& Chandler,2005). Consumer's buy products or services as a solution to fill a need gap. Since so many products are available, they choose a brand after careful evaluations on the attributes (Laroche, Kim, \& Zhou, 1996; Sen \& Bhattacharya, 2001), favourable brand image (Shamma \& Hassan, 2011), and favourable brand attitude (Shim, Eastlick, Lotz, \& Warrington, 2001). Consumers also react to advertisements and other stimulating factors (Wu \& Wang, 2014). Moreover, when consumers are aware about the CSR activities, the recognition of the brand augments well with the consumers' attitude and it, in turn affects the purchase intention (De Wolf, Mejri, \& Lamouchi, 2012).

Many authors believe that the present generation is more aware of corporate social responsibility initiatives than their predecessors and that affects their purchase intentions (Formánková et al.,2019). Millennials (Generation Y) and Generation X believe that firms are investing in Corporate Social Responsibility activities and the purchase intentions of these generations influence the changing trends in CSR.

As per Generation Cohort Theory (Strauss \& Howe,1991), generational cohorts have different experiences which influence their values, preferences and shopping behaviour (Parment, 2011). Numerous empirical studies have clearly pointed out that consumers' spending patterns, attitudes and beliefs vary over the course of an individual's life cycle (Bleichrodt \& Quiggin, 1999; Bodie et al., 2004; Kim et al., 2005; Shepard \& Zeckhauser, 1984). Gen X and Gen Y both have their own set of attitudes and beliefs which influence their purchase intentions (Jorgensen,2003; Lissitsa \& Kol,2016). Gen Y makes decisions faster and without as much negotiation and bargaining as the other generations (Parment,2011). As a result, Gen Y makes more frequent and more impulsive purchases than Gen X (Lissitsa \& Kol,2016).

The Theory of Planned Behaviour continues to evolve and scholars are still building up the theory and adding value to its contents (Yazdanpanah \& Forouzani,2015). The Theory of Planned Behaviour (TPB) (Ajzen,1991) talks about consumer attitudes and their impact on purchase intention. TPB also predicts the behaviour of consumers and its theoretical propositions have been proved empirically (Nigbur et al.,2010). Empirical evidence on purchase intention has been categorized as Individual (Armitage \& 
Conner,2001), Group (Terry \& Hogg,1996), and Interpersonal with Group Intentions (Tajfel \& Turner,1986). These intentions towards the purchase could vary depending on the generation to which the consumer belongs. Perceived CSR beliefs and attitudes and the Theory of generation are therefore the most relevant theories with which to examine this issue.

The main research questions to be answered in this study are threefold. First, it is necessary to examine the association between Perceived Corporate Social Responsibility (CSR) and Purchase Intention. Second, the mediating effect of Brand attitudes on the above relationship needs to be examined and finally, the moderating effect of multi generations (Generation X and Y) on the relationship between Perceived CSR and Purchase Intention. In order to answer the research questions, this study suggests the use of the Theory of Planned Behaviour (Ajzen,1991) and the Generation Cohort's Theory (Strauss \& Howe,1991). Each of these theories has provided the basis of the current understanding in their respective fields, and subsequent literature and theories in the research areas of concern have been broadly based on these theories.

The current study differs from previous research in the area in three important ways. First, this study is a pioneer attempt that proposes six dimensions of corporate social responsibility and consumer purchase intention across multi generations. According to a majority of previous studies, corporate social responsibility is considered to include four dimensions (Schwartz \& Carroll ,2003; Lin ,2010; Lin et al., 2010). Second, previous academic studies have not contributed sufficient understanding of the moderating impact of multi generations (X and $\mathrm{Y}$ ) on the above-mentioned relationship. In other words, many studies have not contributed adequately to prove as to of how CSR impacts consumers' purchase intention across generation $\mathrm{X}$ and $\mathrm{Y}$. Thirdly, academic studies have not sufficiently examined the theoretical impact of the Theory of Planned Behaviour and the Theory of Generational Cohorts from the academic perspective. The impact of perceived corporate social responsibility on purchase intention across multi-generations is an important topic in the current consumer market and there is no prior study exploring the impact of perceived corporate social responsibility on purchase intention across multigenerations (Gen X and Y).

\section{LITERATURE REVIEW}

\subsection{Evolution of Corporate Social Responsibility}

Academics and business managers have experienced how corporate social responsibility has been transformed from a rather irrelevant and controversial idea to a well-accepted topic on research agendas (McWilliams et al., 2006). CSR has also become one of the most orthodox and widely accepted concepts in the business world during recent years (Carroll \& Shabana, 2010). Therefore, the CSR concept has evolved over many decades.

Carroll, (1979) defined four categories of CSR, as Economic Responsibility, Legal Responsibility, Ethical Responsibility and Discretionary Responsibility, which is commonly known as the "Pyramid of CSR" in the contemporary world.

When considering all of the above factors, Carroll (1979) presents the definition of CSR as follows. "The Social responsibility of business encompasses the economic, legal and discretionary expectation that society has of organizations at a given point of time".

As per Carrol (1979), the economic responsibility of a business is to produce goods and services that society desires and to sell them at a profit. The legal responsibility of a business is to adhere to the laws and regulations of the society where it operates. The ethical and philanthropic responsibility of a business is to fulfil the obligations of the business towards society, which extend beyond its economic 
and legal obligations. The philanthropic responsibilities of a business encompass those business actions that are in response to society's expectation that the business be a good corporate citizen.

\subsection{Arguments Against and in Favour of CSR}

Ever since the debate over CSR began, there have been arguments for and against it (Carroll \& Shabana,2010). Friedman's (1984) argument is that a business has only one responsibility which is to maximize profits for its shareholders. Therefore, according to Friedman, social issues are not the concern of business and these problems should be resolved by the free market system. There are a few other arguments against the concept of CSR. Carroll and Shabana (2010) mention that those opposed to the concept of CSR use these arguments even today to defend their views against CSR.

Arguments in favour of CSR typically begin with the belief that it is in business's long-term self-interest - enlightened self-interest - to be socially responsible. This view holds that if business is to have a healthy climate in which to function in the future, it must take action now that will ensure its long-term viability (Carroll \& Shibana, 2010). CSR holds that pro-acting is better than reacting. This basically means that proacting (anticipating, planning and initiating) is more practical and less costly than simply reacting to social problems once they have surfaced (Carroll \& Buchholtz 2009). Finally, it has been argued that business should engage in CSR because the public strongly supports it. Today, the public believes that in addition to its pursuits of profits, business should be responsible to their workers, communities and other stakeholders, even if making things better for them requires companies to sacrifice some profits (Bernstein ,2000). The implementation of corporate social responsibility (CSR) requires firms to identify programs or activities that can give direct benefits to both firms and society (Urip, 2015).

\subsection{Corporate Social Responsibility and Purchase Intention}

Sen and Bhattacharya (2001) confirmed that the level of CSR directly affects consumers' purchase intentions. The behaviours of CSR positively influence consumers regarding the evaluation of the enterprise and the purchase intention (Mohr \& Webb, 2005), where a lower level of CSR will greatly weaken consumers' purchase intention, resulting in consumers who are willing to buy the products just at a lower price. Therefore, CSR activities mould their reactions positively during purchase moments (Mohr \& Webb, 2005). Moreover, CSR will affect consumers' purchase decisions if the consumers are normally prone to socially responsible activities (Prakash \& Pathak, 2017). Authors assume that consumers generally have a low level of CSR awareness (Pomering \& Dolnicar, 2009) and when they are informed of CSR, it positively affects their attitudes (Boyd et al.,2016) and purchase intentions.

In line with the above discussion, the positive effects of CSR on consumer behaviour, and on purchase intention (Carrington et al.,2010; Romani et al.,2016; Lenne \& Vandenbosch, 2017), consumer willingness to pay more for CSR products (Gupta \& Hodges, 2012; Shen et al.,2012; Phau et al.,2015). lower levels of CSR greatly weakening consumers' purchase intention, resulting in consumers who are willing to buy the products just at a lower price (Mohr \& Webb, 2005) were widely evaluated. However, the number of empirical studies on the effect of Corporate Social Responsibility (CSR) motives on consumer purchase intention is still relatively very small (Wongpitch et al., 2016).

\subsection{Brand Attitude and Purchase Intention}

Most of firms are willing to integrate CSR programs into their business strategies for making brand building assistances (Hoeffler, Bloom, \& Keller, 2010). CSR activities have been universal across a 
variation of businesses in various countries and industrial settings (Singh \& Del Bosque, 2007). As per pervious researchers, have acknowledged CSR as a brand building element in today's business settings and have determined that CSR leads to brand loyalty, positive brand relations, and perceived quality contributing holistically toward the growth of brand equity (Chomvilailuk \& Butcher, 2010; Hoeffler \& Keller, 2002; Sprinkle \& Maines, 2010; Yoo, Donthu, \& Lee, 2000).

Attitude is a highly popular concept within many past studies and marketing research papers (Mitchell and Olson, 1981; Banytė, Jokšaitè and Virvilaite, 2007; Schivinski and Dąbrowski, 2013). Due to this reason, there are many definitions available for the attitude. Mitchell and Olson (1981) describing attitude with a more specific reference to brands as 'an individual's internal evaluation of an object such as a branded product. Not only that, Louton and Della Bitta (1993), 'how for or against, positively or negatively, favourably or unfavourably a person regards a particular object'.

Brand attitude entails on the whole evaluation of the brand, which contains factors such as brand awareness, brand image, and brand-based associations of attributes and benefits (Fishbein and Ajzen, 1975; Bruhn et al, 2012). There are also a multitude of reasons for the long-term interest into the area of brand attitude, one of which can be attributed to the fact that attitudes are relatively stable and enduring so therefore are useful predictors of consumer behaviour (Mitchell and Olson, 1981). Attitudes are imperative to marketers as they provide a summary of a consumer's evaluation of the product/service/brand (Belch and Belch, 2003). Brand attitudes, and similarly how they are made, both impact on the ultimate goal of creating a purchase intention among consumers (Sicilia, Ruiz and Reynolds, 2006).

\subsection{Theory of Planned Behaviour (TPB)}

Purchase intentions are personal action tendencies relating to the brand. Intentions are distinct from attitudes, whereas attitudes are summary evaluations. Intentions represent "the person's motivation in the sense of his or her conscious plan to exert effort to carry out a behaviour" (Spears and Singh, 2004). Thus, a concise definition of purchase intentions is, an individual's conscious plan to make an effort to purchase a brand. (Spears and Singh 2004). Other scholars such as Howard (1989) defined that the purchase intention is the probability that a consumer plans to buy a certain brand or product during a certain period of time. The Theory of Planned Behaviour (TPB) (Ajzen,1985) proposes that an individual's intention to perform a specific behaviour is an effective predictor of behaviour. Moreover, attitude is a factor of influencing behaviours through behavioural intentions. The Theory of Planned Behaviour as per Ajzen, (1985), both attitudes toward a behaviour and subjective norm are determinant factors of intention to perform a specific behaviour.

The Theory of Planned Behaviour (TPB) is a recognized intention model that is successful in explaining and predicting behaviour (Grandon,2005). It is an improved model of the Theory of Reasoned Action (TRA) where perceived behavioural control was added as an element to predict intention and behaviour (Mattingly,2012). As per this, intention is a precursor of behaviour and it can be predicted from three variables, namely, attitude toward the behaviour, subjective norms and perceived behavioural control. The first factor, attitude towards the behaviour, refers to the beliefs an individual has with respect to the consequences associated with performing a particular behaviour (Casper, 2007). Also, it can have a corresponding negative or positive judgment associated with it (Francis et al., 2004). The second factor, subjective norms, refers to an individual's own evaluation of the perceived social pressure to perform or not to perform the behaviour (Ajzen,1991). It incorporates views about how other individuals would like them to behave and the negative or positive judgments about each belief. It is presumed that these components work in interaction (Francis et al.,2004). The third factor, perceived behavioural control, is a person's perception of the struggle or ease associated with accomplishing the behaviour (Ajzen,1991). It has two aspects that comprise mainly of whether or not an individual feels confident 
about performing the behaviour and how much control the person thinks he or she has over the said behaviour (Francis et al., 2004). When the above three factors positively impact on behaviour, the individual's purchase intention should be stronger (Ajzen,1991), whereas a negative impact will weaken the purchase intention. The Theory of Planned Behaviour, thus, is a recognized intention model than can be used to predict intention and behaviour (Reynaldo et al., 2017).

\subsection{Generation and Purchase Intention}

According to Ranaweera and Dharmasiri (2016) and Mendis and Dharamasiri (2019), consumers consisting of Gen $\mathrm{X}$ and $\mathrm{Y}$ are active in the Sri Lankan market and in the workforce. Therefore, two generations (Gen $\mathrm{Z}$ and Baby Boomers) have been removed from the scope of the current study and the other two generations (Gen X and Y) were considered in the study. The Generation Y cohort, sometimes called Millennials, is an important cohort and a target audience of retailers and consumer product companies alike because it is sizeable and has significant purchasing power.

However, there is reason to assume that certain attributes that influence purchasing power differ across generational cohorts (Parment,2011), which suggests that studying purchasing behaviour of generational cohorts could be very beneficial. For example, Generation Y spends more effort on highinvolvement product decisions than earlier generations (Parment,2011). Brand and self-identity are the factors that most shape Gen-Y consumers' attitudes towards fashion apparel. Furthermore, brand, style, price, and social identity are the most influential factors that influence Gen-Y consumers' purchase intention for fashion apparel. The findings also show that the country of origin and self-identity do not have any relationship with Gen-Y consumers' purchase intentions (Giovannini et. al., 2015).

\subsection{Generation Cohort's Theory (GCT)}

Generation Cohort's Theory was introduced by Strauss and Howe (1992), states that the people of the same generation may look at the world in common ways and share common values and opinions (Patterson, 2007; Smola \& Sutton,2002). This point of view is shared by Johnson and Johnson (2010), who define a generation as "a group of individuals born and living contemporaneously, who have common knowledge and experiences that affect their thoughts, attitudes, values, beliefs, and behaviours" (Johnson \& Johnson, 2010). However, the definitions of generational boundaries are inconsistent in the literature. For the purpose of this study, the following generally accepted boundaries are used: (1) Traditionalists, born 1925 - 1945 (2) Baby Boomers, born 1946 - 1964 (3) Generation X, born 1965 - 1980 (4) Generation Y, born 1981 - 2000 (5) Generation Z, born after 2000.

Valaei \& Nikhashemi (2017), pointed out that Generational factors (Generation-Y) influence purchase intention. In line with this, Valaei \& Nikhashemi (2017), provided insights into what constitute GenY's consumer attitudes and perceived purchase intention.

\section{HYPOTHESES AND CONCEPTUAL FRAMEWORK}

\subsection{Perceived Corporate Social Responsibility Initiatives and Purchase Intention}

The Theory of Planned Behaviour (TPB) is a recognized intention model in explaining and predicting purchase intention in the presence of certain attitudes, beliefs and controls (Grandon,2005). Perceived CSR generates beliefs within consumers' minds and creates impulses which give rise to the purchase intention. In 2001, Sen \& Bhattacharya, (2001) confirmed that the level of CSR directly influences consumers' purchase intention. Moreover, the CSR behaviour of companies positively influences consumers to evaluate the enterprise and generates purchase intention (Mohr \& Webb, 2005). Why then 
has the intention not become actual purchase behaviour? It is argued that consumers' non-engagement in socially responsible purchasing is due to negative net values perceived about socially responsible purchasing (D'Astous \& Legendre, 2009). Some previous research indicates that CSR factors are far less important to consumers' purchase decisions than product attributes such as price, aesthetics and quality (Abraham-Murali \& Littrell, 1995; Eckman et al., 1990). Based on these findings, the following hypothesis is formulated.

\section{H1: Perceived Corporate Social Responsibility Impacts Consumer Purchase Intention}

\subsection{Perceived CSR initiatives and Brand Attitude}

Brand attitude is the customers' reaction towards a brand and his/her liking to a brand, and it is useful in predicting the responses to the marketing activities (Howard, 1994). Brand attitude is determined by familiarity and confidence customers have on a brand; the more the familiarity and confidence, the more the purchase intention will be. Although brand attitude and purchase intentions are related (Casper, 2007), brand attitude is a summary evaluation made by the customer. Purchase intention is the behavioural attitude of the customer; it is not same feeling the customer has toward a brand, but the motivation or conscious plan for an action the consumer to perform (Spears \& Singh, 2004). Lii and Lee (2012) found that there is a strong relationship between brand attitude and purchase intention in the context of CSR. By this, the following hypothesis is formed.

\section{H2: Perceived Corporate Social Responsibility has a significant impact on Brand Attitude}

\subsection{Brand Attitude and Purchase Intention}

Purchase intentions is an individual's mindfulness to make an effort to purchase a brand or product (Spears and Singh, 2004). In other words, purchase intentions are personal action tendencies toward the brand, whereas attitudes are overall evaluations. Intentions stand for the person's motivation which plans to exert effort to carry out a behaviour (Eagly and Chaiken, 1993). Other scholars such as Howard (1989) defined that the purchase intention is the probability that a consumer plans to buy a certain brand or product during a certain period of time. The Theory of Planned Behaviour (TPB) (Ajzen, 1985) proposes that an individual's intention to perform a specific behaviour is an effective predictor of behaviour. Moreover, attitude is a factor of influencing behaviours through behavioural intentions. Within the parameters of the Theory of Planned Behaviour (Ajzen, 1985), both attitudes toward a behaviour and subjective norms are determinant factors of intention to perform a specific behaviour. Furthermore, behaviour intention can be directly used to predict behavioural achievement. In summary, purchase intention is an accuracy factor of predicting actual purchase behaviour. Brand attitude and purchase behaviour are important and widely studied variables in consumer behaviour research (Spears and Singh 2004). Based on the above arguments, it is hypothesized that:

\section{H3: Brand Attitude has a significant impact on consumers' purchase intention.}

Brand Attitude mediates the relationship between Perceived Corporate Social Responsibility and Consumer Purchase Intention. Brand attitude is an important element as it is being used to envisage customers buying preferences (Chaudhuri, 1999). Companies need to recognize their loyal buyers and hence further explore their brand fondness. It reflects consumers' likes or dislikes; thus, it is a useful basis of consumers' willingness and brand loyalty (Burton, Lichtenstein, Netemeyer, \& Garretson, 1998). Some studies (Becker-Olsen, Cudmore, \& Hill, 2006) indicate that consumers perceive CSR as an influencing criterion for holding their beliefs, attitude, and purchase intention. By this, the following hypothesis is formed: 
H4: Brand attitude mediates the relationship between Perceived Corporate Social Responsibility and Consumer Purchase Intention

\subsection{The relationship between Brand Attitude and Purchase Intention examined across multi- generations}

Gen $\mathrm{X}$ has highest rate of brand loyalty and brand attitude. But Gen $\mathrm{X}$ is less interested in trying new brands compared to than other generations and instead stick to those they know. (Graywood,2018). Perhaps the most fact about Gen X in the study is their extreme brand loyalty and brand attitude, relative to that of millennials and baby boomers (Lamn,2017). But, Generation Y consumers have higher Brand attitude than other generation (Lazarevic,2012).

When generation $\mathrm{Y}$ consumers find brands that consistently match their values and have a brand image that matches their self-image, they will be motivated to develop a positive attitude with this brand. This is due to generation $\mathrm{Y}$ consumers beginning to develop to have an attitude the brand to consistently convey the right image of themselves to others when the brand is consumed (Sullivan \& Heitmeyer 2008). They begin to feel a connection to the brand because the brand allows them to be who they want to be (Aaker 1997). Once this connection, is formed the generation Y consumer will turn to that brand more often (Noble et al. 2009) and this leads to brand loyalty and brand attitude (Pasovac et al. 1997). Based on the above arguments, it is hypothesized that:

H5: The impact of Brand Attitude on Purchase Intention is moderated by multi-generations (Generation $X \& Y)$

\subsection{Perceived CSR initiatives and Purchase Intention across multi-generations}

As a financially powerful generation (Grant and Stephen, 2005), Gen-Y consumers are capable of influencing the spending habits of their parents (Lee Taylor and Cosenza, 2002), and they constitute an attractive segment for marketers to reach out to as the purchasing power and population of this generational cohort is increasing (Naser \& Nikhashemi,2017). Gen-Y consumers exhibit disparities in their behaviour and this urges marketers to comprehend their attitudes in order to be innovative and come up with new ways to attract this lucrative consumer segment (Grant \& Stephen,2005). Based on the above arguments, it is hypothesized that:

H6: The impact of perceived CSR initiatives on purchase intention is moderated by multi-generations (Generation $X \& Y$ ) 
Figure 1: conceptual Framework of the Study

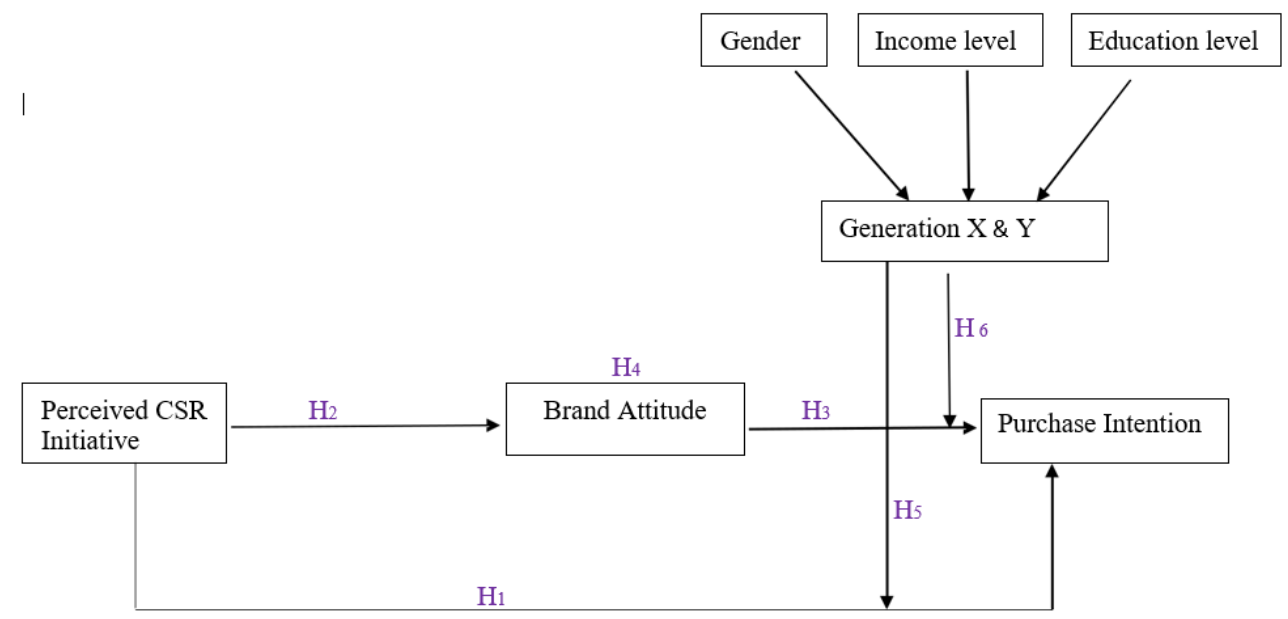

Source: Author

\section{METHODOLOGY}

\subsection{Participants and procedures}

This research followed the deductive method to arrive at a rational conclusion by logical generalization from a known fact. The unit of analysis of this study was the individual and the research was in the form of a cross- sectional study. The current study is grounded on positivism, and is a non-contrived study (Saunders et al.,2009).

With the quantitative approach to the study, data was gathered using a structured questionnaire. A sample of 475 individuals were used to gather data. With 430 respondents and 38 outliers, the final sample was $392(n=392)$. The pilot study was carried out for each variable using a measurement scale of $1-7$.

\subsection{Measures}

Perceived CSR consists of six basic dimensions of CSR, namely, economic, environmental, social, philanthropic, ethical and legal (Dahlsrud,2008) and each dimension was measured in a different weighted questionnaire (Bianchi \& Sarabia-Sanchez,2019), The research focused particularly on the social dimension because it is considered the most difficult dimension to measure (Beske-Janssen et al., 2015; Bianchi \& Sarabia-Sanchez,2019). Brand Attitude construct was assessed based on the item scale suggested by Erdem and Swait (2004). Purchase intention was measured on a scale with twelve items anchored, adopted from Pradhan (2018) Chania and Weiping (2014), and Dotson and Hyatt (2005).

\subsection{Data Analysis and Results}

Data were tested for Common Method Variance (CMV) and multivariate assumptions, including tests for normality, linearity, homoscedasticity, multicollinearity and heteroscedasticity, before forwarding the measurement model for confirmatory factor analysis (Galahitiyawa,2013). In line with Hair et al., (2011), items which had factor loading values less than 0.5 were removed (INT1 \& INT2) and the model 
was re-tested for validity. Thereafter, statistics for validity and reliability were calculated with the standardized factor loadings. The results of the reliability and validity testing are reported in Table 1.

Table 1: Reliability and validity measurements

\begin{tabular}{|c|c|c|c|c|c|c|c|}
\hline \multirow{2}{*}{ Variable } & \multirow{2}{*}{$\begin{array}{l}\text { No. of } \\
\text { items }\end{array}$} & \multirow{2}{*}{$\begin{array}{l}\text { Cronbach's } \\
\text { Alpha }\end{array}$} & \multirow{2}{*}{$\begin{array}{l}\text { Composite } \\
\text { Reliability }\end{array}$} & $\begin{array}{l}\text { Average } \\
\text { Variance } \\
\text { Extracted }\end{array}$ & \multicolumn{3}{|c|}{ Discriminant validity } \\
\hline & & & & $\begin{array}{l}\text { Extracted } \\
(\mathrm{AVE})\end{array}$ & BA & INT & PCSR \\
\hline$\overline{\mathrm{BA}}$ & 5 & 0.918 & 0.939 & 0.754 & 0.868 & & \\
\hline INT & 10 & 0.898 & 0.917 & 0.533 & 0.665 & 0.730 & \\
\hline PCSR & 11 & 0.926 & 0.938 & 0.578 & 0.786 & 0.579 & 0.915 \\
\hline
\end{tabular}

Note: (1)BA-Brand Attitude ;(2)INT-Purchase Intention; (3) PCSR-Perceived Corporate Social Responsibility.

The statistics depicted in Table 1 reflects that all the latent variables in the model have appropriate levels of convergent validity (>0.7), composite reliability (CR>0.7) (Hair et al.,2011), and internal consistency $(\alpha>0.7)$. All constructs met these criteria and discriminant validity (AVE $>$ SMC) was equal to 0.5 or more (Bock et al.,2005). This was assumed to be a good indication of convergent validity (Hair et al.,2011), and all constructs met this criterion.

Cohen's Indictor (f2), was calculated by the inclusion and exclusion of each of the variables (one at a time). It illustrates how the measured variance explains each exogenous variable in the models. The values of the explained variances are $0.02,0.15$ and 0.35 , respectively, and are considered to be small, medium and large (Hair et al.,2012). As the analysis revealed, facilitating conditions has a small effect (f2=0.039) on PCSR $\rightarrow$ INT, a medium effect (f2=0.165) on BA $\rightarrow$ INT and a large effect (f2=1.607) on PCSR -> BA. In addition, Hair et al., (2012) recommended that researchers should assess StoneGeisser's Q2 value. This has been used as a supplementary measure to the assessment of goodness-offit in Partial Lest Squares-Structural Equation Modelling (Richter et al.,2015). A research model with Q2 value(s) greater than zero is considered to have predictive relevance (Henseler et al.,2009). In the current research, all variables listed under Q2 had values greater than 0, and therefore, model fit is established through predictive relevance $(\mathrm{Q} 2)$.

\subsection{The structural model}

\section{Assessment of direct relationships}

After ensuring that the construct measurement indicators were reliable and valid, the next step was to generate the structural model results.

Table 2: Path Coefficients of the Structural Model for Control Variables

\begin{tabular}{llllll} 
& \multicolumn{3}{c}{ Standard } & & \\
Relationship & $\beta$ Value & Deviation & T Statistics & P Values & Decision \\
& & $($ STDEV $)$ & $(|\mathrm{O} / \mathrm{STDEV}|)$ & & \\
& & & & \\
\hline Education Level -> INT & 0.078 & 0.063 & 1.134 & 0.350 & Not Supported \\
Income Level -> INT & 0.067 & 0.059 & 1.126 & 0.260 & Not Supported
\end{tabular}




\begin{tabular}{|c|c|c|c|c|c|}
\hline Civil statues -> INT & 0.076 & 0.051 & 1.141 & 0.250 & Not Supported \\
\hline
\end{tabular}

Source: Survey data

As per Table 2, Education Level -> INT p-value is 0.350, Income Level -> INT p-value is 0.260 and Civil statues -> INT relevant p-value is 0.250 . Based on the above analysis, all p-values are higher than 0.05 and therefore the relationship between the control variable and Generation is not significant.

Table 3: Path Coefficients of the Structural Model

\begin{tabular}{lllcllll}
\hline Hypothesis & Relationship & std Beta & $\begin{array}{c}\text { Mean } \\
(\mathbf{M})\end{array}$ & $\begin{array}{l}\text { Std } \\
\text { Error }\end{array}$ & $\begin{array}{l}\mid \mathbf{t}- \\
\text { value }^{\wedge}\end{array}$ & $\begin{array}{c}\text { P } \\
\text { Values }\end{array}$ & Decision \\
\hline H1 & PCSR -> INT & 0.614 & 0.616 & 0.038 & 16.223 & $0.000^{* *}$ & Supported \\
H2 & PCSR -> BA & 0.786 & 0.785 & 0.023 & 34.365 & $0.000^{* *}$ & Supported \\
H3 & BA -> INT & 0.664 & 0.666 & 0.034 & 19.619 & $0.000^{* *}$ & Supported \\
\hline
\end{tabular}

Note: Significant level; $* P<0.1 ; * * P<0.05 \mid P C S R$-Perceived Corporate Social Responsibility, BA-Brand Attitude, INTPurchase Intention

Source: Survey data

As per Table 3, the relationship between Perceived Corporate Social Responsibility and Consumer Purchased Intention (PCSR -> INT), Perceived Corporate Social Responsibility and Brand Attitude (PCSR -> BA) and Brand Attitude and Purchase Intention had (BA -> INT) of P-values of 0.000 and effects are medium, high and medium, respectively. The relevant $\mathrm{P}$-values of all relationship are 0.000 which are less than 0.05 , and hence, all direct effects are significant. Therefore, the above mentioned direct effects were found to be statistically significant (Weerasinghe \& Jayawardana,2019).

\section{Assessment of Mediating Effect}

To test the mediating effect of brand attitude on the relationship between perceived corporate social responsibility and consumer purchase intention, the bootstrapping method was applied using SMART PLS. In the mediator analysis, all the direct and indirect paths were tested as per Baron and Kenny (1986) analysis.

Table 4: Path Coefficients of the Mediator

\begin{tabular}{|c|c|c|c|c|c|}
\hline \multirow{5}{*}{ Relationship } & \multirow{5}{*}{$\beta$ Value } & \multicolumn{3}{|c|}{ Standard } & \multirow{3}{*}{$\mathrm{P}$} \\
\hline & & Sample & & T Statistics & \\
\hline & & \multirow{2}{*}{\multicolumn{2}{|c|}{ Deviation }} & & \\
\hline & & Mean (M) & & (|O/STDEV $\mid)$ & Values \\
\hline & & & (STDEV) & & \\
\hline PCSR -> INT & 0.234 & 0.231 & 0.072 & 3.230 & $0.001 * *$ \\
\hline PCSR $->$ BA & 0.786 & 0.785 & 0.024 & 32.225 & $0.000 * *$ \\
\hline BA $\rightarrow$ INT & 0.481 & 0.485 & 0.069 & 6.946 & $0.000 * *$ \\
\hline
\end{tabular}

Note: Significant level; $* P<0.1 ; * * P<0.05$

PCSR-Perceived Corporate Social Responsibility, BT-Brand Attitude, INT-Purchase Intention

In addition, the mediating impact was tested by Indirect Effect Calculation and the Sobel Test. Indirect effect/ Total effect was $54 \%$ and the direct effect showed a value of $47 \%$, . As per this calculation, $54 \%$ mediation is shown by this model (PCSR $\rightarrow$ BA and BA $\rightarrow$ INT) and the Sobel test value is 6.9. Therefore, this model illustrates partial mediation (Kenny et al.,1998). The alternative hypothesis (H4) is accepted. 


\section{Assessment of the Moderating Effect of Generation}

A categorical variable is tested where group effects are clear, and here, a logical multi group analysis (PLS-MGA) method was used for test the moderating impact (Hair et al.,2012). As per Table 5, the relationships between Perceived Corporate Social Responsibility and Consumer Purchase Intention (PCSR -> INT), and Brand Attitude and Consumer Purchase Intention had (BA -> INT) P-values of 0.000 , and since these values are less than 0.05 , the moderating effects exerted by Generation on the two relevant relationships were significant.

Table 5: Moderating Effect -> Generation

\begin{tabular}{|l|l|l|l|l|l|l|}
\hline Hypothesis & Relationship & $\boldsymbol{\beta}$ & $\begin{array}{l}\text { Standard } \\
\text { Deviation } \\
(\text { VTDEV) }\end{array}$ & $\begin{array}{l}\text { T Statistics } \\
(\mid \mathbf{O} / \text { STDEV|) }\end{array}$ & $\begin{array}{l}\text { P } \\
\text { Values }\end{array}$ & \\
\hline H5 & $\begin{array}{l}\text { Generation* PCSR -> } \\
\text { INT }\end{array}$ & 0.614 & 0.038 & 15.966 & $0.000^{* *}$ & Supported \\
\hline H6 & $\begin{array}{l}\text { Generation* BT -> } \\
\text { INT }\end{array}$ & 0.666 & 0.035 & 19.121 & $0.000^{* *}$ & Supported \\
\hline
\end{tabular}

Note: Significant level; $* P<0.1 ; * * P<0.05$

PCSR-Perceived Corporate Social Responsibility, BA-Brand Attitude, INT-Purchase Intention

Source: Survey data

PLS-MGA provides better facilities to go deeper at this stage of the research. A further analysis of this moderating impact of each generation (Gen X and Gen Y) on these relationships, yields the following results, as shown in Table 6.

Table 6: Moderating Effect -> Generation $X$ and $Y$

\begin{tabular}{|l|l|l|l|}
\hline & $\boldsymbol{\beta}$ Value & $\begin{array}{l}\text { T Statistics } \\
(\mid \mathbf{O} / \text { STDEV })\end{array}$ & P Values \\
\hline Generation-X* BA -> INT & 0.651 & 11.248 & $0.000^{* *}$ \\
\hline Generation-Y* BA -> INT & 0.581 & 13.925 & $0.000^{* *}$ \\
\hline Generation-X* PCSR -> INT & 0.574 & 10.026 & $0.000^{* *}$ \\
\hline Generation-Y* PCSR -> INT & 0.651 & 23.678 & $0.000^{* *}$ \\
\hline
\end{tabular}

Note: Significant level; $* P<0.1 ; * * P<0.05$

Source: Survey data

PCSR-Perceived Corporate Social Responsibility, BA-Brand Attitude, INT-Purchase

Intention

The impact of Generation-(X/Y) on the BA -> INT relationship and the impact of Generation-(X/Y) on the PCSR -> INT relationship are statically significant and indicates the moderating impact. However, the moderating impact of Generation-(X/Y) on BA -> INT is low, as per the analysis of PLS MGA0.019, Welch-Satterthwait Test-0.017, and the Parametric Test 0.02. However, the moderating impact of Generation-(X/Y) on PCSR -> INT is significant. All the alternative hypotheses (H1 to H6) formulated in the current study were accepted.

\section{DISCUSSION}

Outcome of this study reveals that a significant direct relationship was found between Perceived corporate social responsibility and Purchase intention. This result confirms previous research studies (Sen \& Bhattacharya,2001; Mohr \& Webb, 2005; D’Astous \& Legendre, 2009; Leonidou et al.,2012).

The study also revealed that, Perceived Corporate Social Responsibility impacts purchased intention directly (H1). As per Fatma \& Rahman (2016), when Perceived Corporate Social Responsibility impacts 
purchased intention directly, it converts consumers' belief in CSR activities into positive cognition (intention) that is reflected in increased purchase intention. As per the theory of planned behaviour (Ajzen,1991), belief and attitudes enhance consumer purchase intention.

The findings revealed there is a significant effect of Perceived corporate social responsibility and Brand attitude (H2). It is important to understand the relative importance of business ethics and social responsibility in determining brand attitudes (Ferrell et al.,2019). When the consumer believes that CSR is the right thing to do and when they observe an organization involved in their intended way, they tend to create favourable attitude. Since consumers are aware about the organization's CSR activities and its brands, it is possible to form attitudinal responses to both firm's CSR and brand (Wong pitch et al., 2015).

The study also found significant impact of Brand attitude to Purchase intention (H3). This tallies with the findings of (He et al.,2015; Salehzadeh \& Pool,2016). As well as the findings of Vila and Kuster, (2011; Hernández \& Küster (2012).

Brand attitude was found to be a significant partial mediator of the relationship between to CSR and Purchase intention (H4). Kim et al., (2015) stated that CSR managers should pay attention to corporate brand trust, brand attitude as a more efficient means of reducing negative consumer attitudes toward corporations. Furthermore, Lee and Trail (2009) found brand attitude act as the mediating effect of purchase intention.

$\mathrm{H} 5$ and $\mathrm{H} 6$ were accepted through the results of data analysis. This confirms not only that Generation $\mathrm{X}$ and $\mathrm{Y}$ significantly moderate the relationships between Perceived corporate social responsibility and Purchase intention and Brand attitude and Purchase intention but also overcome the inconsistencies and the lacuna that existed in the empirical research.

Gen-Y is very interested in which brands are ethical, caring, and trusting, and strive to do the right thing. Gen Y looks primarily at the mission of companies and the charitable aspects of that mission. For many in Gen Y, companies have to earn brand trust and brand attitude through their socially responsible actions (Selko, 2018). Garbarino and Johnson (1999) and Wu and Lin (2014) demonstrate that consumers' attitude towards a brand established by an organization influences their future intentions (including future attendance, subscriptions, and donations) toward the organization. $\mathrm{Wu}$ and Wang, (2014) discussed about the Brand attitude and purchase intention in detail.

\subsection{Theoretical Contribution}

The current paper examined both direct and indirect (mediating impact of brand attitude) impacts across multi generations by using the Theory of Planned Behaviour (TPB) underpinned by the Generational Cohort's Theory, and this approach has not been taken before. This study proved that perceived CSR creates attitudes that will lead to purchase intention.

The findings of the current study revealed that the moderating impact of Gen $\mathrm{Y}$ is higher than that of Gen X. Therefore, Gen Y consumers' attitudes and beliefs related to perceived CSR are generally stronger than those of Gen X. Consequently, consumer beliefs and attitudes towards purchase intention depend on multi-generations. Previous studies and theories do not shed light on perceived CSR and customer purchase intention in this context.

\subsection{Managerial Implication}

Firstly, the study advocates creative and innovative advertising based on generational criteria. as, perceived corporate social responsibility affects purchase intentions of consumers across the two 
generations (Generation $\mathrm{X}$ and $\mathrm{Y}$ ) positively. Generation $\mathrm{Y}$ is highly environmentally oriented (Wu \& Wang,2014) and they are very attuned to social media (Bolton et al.,2013). Based on that, firms will be able to communicate their CSR activities through social media. In particular, Gen-X is more emotional, while Gen-Y is more easy-going with a happy-go-lucky attitude. Therefore, firms will be able to craft their advertising based on their CSR activities to target particular generations.

Secondly, this paper provides useful information to companies to select the proper communication tool/method to deliver their CSR message. The social media marketing medium has become an important marketing tool to reach emerging generation Y-consumers (Balakrishnan et al.,2014; Nadeem et al.,2015), and Gen-Y is distinguished from other generational cohorts in its intense exposure to the Internet (Acheampong et al.,2017). Gen-X generally prefers receiving and using short, brief messages as texts or emails as opposed to lengthy ones (NDMU,2019), due to their busy work schedules. Therefore, companies will be able to deliver their CSR activities by using different and targeted communication tools based on the generation they need to reach.

Thirdly, this study provides a practical understanding on how to overcome competitive barriers to CSR and consumer purchase intentions for the betterment of society as well as of the industry mainly through perceived corporate social responsibility, rapid penetration will lead to the creation of impulse purchase decisions among current consumers. In particular, Gen-Y is more aware of CSR activities and their buying behavior depends on the brands that are associated with CSR. Therefore, brand managers can combine social elements when they are articulating brand slogans and brand mantras for CSR based brand products.

Finally, this study provides a practical understanding of the implementation of CSR activities. Gen X and $\mathrm{Y}$ consumers are mainly considered when discussing environment-based CSR activities

\subsection{Limitations and further research}

There were a few limitations in this study which can be examined by future research. One limitation is that the findings of the research was based on one province consisting three districts. Another limitation of this study is that the qualitative and quantitative approaches of this study could have been integrated to yield the mixed method approach through which the findings could have been further clarified, thus enhancing the parameters of the findings. Future studies can also consider on several provinces as well as on industry wise.

\section{CONCLUSION}

The aim of this paper was to ascertain the impact of multi generations (Gen's X and Y) on perceived CSR, brand attitude and purchase intention based on the current theoretical and empirical evidence. The findings of this study corroborated the existing empirical evidence that supports the direct relationship between perceived CSR and Purchase intention and Brand attitude and Purchase intention. Furthermore, brand attitude was found to mediate the relationship between CSR and Purchase intention and multi generations (Gen's $\mathrm{X}$ and $\mathrm{Y}$ ) were found to moderate it. The moderating impact of Gen $\mathrm{Y}$ was higher than that of Gen X. Therefore, this paper posits that the impact of perceived corporate social responsibility on purchase intention is positive across multi generations (Gen $\mathrm{X}$ and $\mathrm{Y}$ ) and that this relationship is mediated by brand attitude. 


\section{REFERENCES}

Aaker, J. (1997). Dimensions of Brand Personality. Journal of Marketing Research, 34(3), $347-356$. doi: $10.2307 / 3151897$

Abraham-Murali, L., \& Littrell, M. A. (1995). Consumers Conceptualization of Apparel Attributes. Clothing and Textiles Research Journal, 13(2), 65-74. doi:10.1177/0887302x9501300201

Acheampong, G., Narteh, B., \& Rand, J. (2017). Network ties and survival. The International Journal of Entrepreneurship and Innovation, 18(1), 14-24. doi:10.1177/1465750316685337

Ackerman, R. W. (1973). How companies respond to social demands. Harvard: Harvard Business Review.

Ajzen, I. (1985). From Intentions to Actions: A Theory of Planned Behavior. Action Control, 11-39. doi:10.1007/9783-642-69746-3_2

Ajzen, I. (1991). The theory of planned behavior. Organizational Behavior and Human Decision Processes, 50(2), 179-211. doi:10.1016/0749-5978(91)90020

Armitage, C. J., \& Conner, M. (2001). Efficacy of the Theory of Planned Behaviour: A meta-analytic review. British Journal of Social Psychology, 40(4), 471-499. doi:10.1348/014466601164939

Balakrishnan, B. K., Dahnil, M. I., \& Yi, W. J. (2014). The Impact of Social Media Marketing Medium toward Purchase Intention and Brand Loyalty among Generation Y. Procedia Social and Behavioral Sciences, 148, 177185. doi: 10.1016/j.sbspro.2014.07.032

Banytė, J, Jokšaitė, E, \& Virvilaitė, R.(2007).Relationship of Consumer Attitude and Brand: Emotional Aspect. Engineering Economics, 52(2).65-77

Becker-Olsen, K. L., Cudmore, B. A., \& Hill, R. P. (2006). The impact of perceived corporate social responsibility on consumer behavior. Journal of Business Research, 59(1), 46-53. doi:10.1016/j.jbusres.2005.01.001

Belch, G. and Belch, A. (2003).Advertising and Promotion: An Integrated Marketing Communications Perspective, New York. McGraw-Hill. 6th edn.

Bernstein, A. (2000). Too Much Corporate Power? (2000, September 11). Retrieved from https://www.bloomberg.com/news/articles/2000-09-10/too-much-corporate-power

Bianchi, E., Bruno, J. M., \& Sarabia-Sanchez, F. J. (2019). The impact of perceived CSR on corporate reputation and purchase intention. European Journal of Management and Business Economics, 28(3), 206-221. doi: 10.1108/ejmbe-12-2017-0068

Bleichrodt, H., \& Quiggin, J. (1999). Life-cycle preferences over consumption and health: When is cost-effectiveness analysis equivalent to cost-benefit analysis? Journal of Health Economics, 18(6), 681-708. doi:10.1016/s01676296(99)00014-4

Bock, Zmud, Kim, \& Lee. (2005). Behavioural Intention Formation in Knowledge Sharing: Examining the Roles of Extrinsic Motivators, Social-Psychological Forces, and Organizational Climate. MIS Quarterly, 29(1), 87. doi: $10.2307 / 25148669$ 
Boccia, F., \& Sarnacchiaro, P. (2017). The Impact of Corporate Social Responsibility on Consumer Preference: A Structural Equation Analysis. Corporate Social Responsibility and Environmental Management, 25(2), 151-163. doi:10.1002/csr.1446

Bolton, R. N., Parasuraman, A., Hoefnagels, A., Migchels, N., Kabadayi, S., Gruber, T., Solnet, D. (2013). Understanding Generation Y and their use of social media: a review and research agenda. Journal of Service Management, 24(3), 245-267. doi: 10.1108/09564231311326987

Boyd, D. E., Mcgarry, B. M., \& Clarke, T. B. (2016). Exploring the empowering and paradoxical relationship between social media and CSR activism. Journal of Business Research, 69(8), 2739-2746. doi:10.1016/j.jbusres.2015.11.009

Bruhn, M., Schoenmueller, V., and Scafer, D. (2012). Are social media replacing traditional media in terms of brand equity creation? Management Research Review, 35(9), 770-790.

Burton, S., Lichtenstein, D. R., Netemeyer, R. G., \& Garretson, J. A. (1998). A scale for measuring attitude toward private label products and an examination of its psychological and behavioral correlates. Journal of the Academy of Marketing Science, 26(4), 293-306. https://doi.org/10.1177/0092070398264003

Carrington, M. J., Neville, B. A., \& Whitwell, G. J. (2010). Why Ethical Consumers Don't Walk Their Talk: Towards a Framework for Understanding the Gap Between the Ethical Purchase Intentions and Actual Buying Behaviour of Ethically Minded Consumers. Journal of Business Ethics, 97(1), 139-158. doi:10.1007/s10551-010-0501-6

Carroll, A. B. (1979). A Three-Dimensional Conceptual Model of Corporate Performance. The Academy of Management Review, 4(4), 497-505. doi: 10.2307/257850

Carroll, A. B. (1991). The pyramid of corporate social responsibility: Toward the moral management of organizational stakeholders. Business Horizons, 34(4), 39-48. doi: 10.1016/0007-6813(91)90005-g

Carroll, A.B., and Schwartz, M.S. (2003 ). Corporate Social Responsibility: A Three-Domain Approach. Business Ethics Quarterly, 13 (4), 503-530, doi: 10.2307/3857969

Carroll, A. B., \& Buchholtz, A. K. (2009). Business \& Society: Ethics and Stakeholder Management. Stamford, CT: Cengage Learning.

Carroll, A. B., \& Shabana, K. M. (2010). The Business Case for Corporate Social Responsibility: A Review of Concepts, Research and Practice. International Journal of Management Reviews, 12(1), 85-105. doi: 10.1111/j.1468-2370.2009. 00275.x

Casper, E. S. (2006). Increasing the Utilization of Supported Employment ServicesWith the Need for Change Scale. Psychiatric Services, 57(10), 1430-1434.

Chaudhuri, A.(1999).The Effects of Brand Attitudes and Brand Loyalty on Brand Performance. Association for Consumer Research, 4,276

Chen, J.-S., Ching, R., Tsai, H.-T., \& Kuo, Y.-J. (2008). Blog effects on brand attitude and purchase intention. 2008 International Conference on Service Systems and Service Management. doi: 10.1109/icsssm.2008.4598562

Chengalur-Smith, I., Duchessi, P., \& Gil-Garcia, J. R. (2012). Information sharing and business systems leveraging in supply chains: An empirical investigation of one web-based application. Information \& Management, 49(1), 5867. doi: 10.1016/j.im.2011.12.001 
Chin, W. W. (1998). The partial least squares approach to structural equation modelling. Modern methods for business research, 295(2), 295-336.

Chomvilailuk, R., \& Butcher, K. (2010). Enhancing brand preference through corporate social responsibility initiatives in the Thai banking sector. Asia Pacific Journal of Marketing and Logistics, 22(3), 397-418. doi: $10.1108 / 13555851011062296$

Creyer, E. H. (1997). The influence of firm behavior on purchase intention: Do consumers really care about business ethics? Journal of Consumer Marketing, 14(6), 421-432. doi:10.1108/07363769710185999

Dahlsrud, A. (2008). How corporate social responsibility is defined: an analysis of 37 definitions. Corporate Social Responsibility and Environmental Management, 15(1), 1-13. doi: 10.1002/csr.132

Davis, K. (1967). Understanding the social responsibility puzzle. Business Horizons, 10(4), 45-50. doi: 10.1016/00076813(67)90007-9

D’Astous, A., \& Legendre, A. (2008). Understanding Consumers' Ethical Justifications: A Scale for Appraising Consumers' Reasons for Not Behaving Ethically. Journal of Business Ethics, 87(2), 255-268. doi: $10.1007 / \mathrm{s} 10551-008-9883-0$

David, P., Kline, S., \& Dai, Y. (2005). Corporate Social Responsibility Practices, Corporate Identity, and Purchase Intention: A Dual-Process Model. Journal of Public Relations Research, 17(3), 291-313. doi:10.1207/s1532754xjprr1703_4

Delgado-Ballester, E., \& Munuera-Alemán, J. L. (2001). Brand trust in the context of consumer loyalty. European Journal of Marketing, 35(11/12), 1238-1258. doi: 10.1108/eum0000000006475

De Wolf,D., Mohamed,M., \& Lammouchi,R. (2012). How do Multi-National Corporations CEOs perceive and communicate about Social Responsibility. Research Journal of Finance and Accounting, 3(1),18-34

Dodds, W. B., Monroe, K. B., \& Grewal, D. (1991). Effects of price, brand, and store information on buyers 'product evaluations. Journal of Marketing Research, 28(3), 307-319. http://dx.doi.org/10.2307/3172866

Doney, P., \& Cannon, J. (1997). An Examination of the Nature of Trust in Buyer-Seller Relationships. Journal of Marketing, 61(2), 35-51. doi:10.2307/1251829

Dotson, M. J., \& Hyatt, E. M. (2005). Major influence factors in children's consumer socialization. Journal of Consumer Marketing, 22(1), 35-42. doi:10.1108/07363760510576536

Eagly, A. H., \& Chaiken, S. (1993). The psychology of attitudes. Belmont: Wadsworth Cengage Learning.

Eckman, M., Damhorst, M.L., and Kadolph, S.J. (1990). Towards a model of the in-store purchase decision process: consumer use of criteria for evaluating women's apparel. Clothing and Textiles Research Journal, 8(2), 13-22.

Eells, R and Walton, C.C. (1961). Conceptual foundations of business. Homewood, Ill.: Richard D. Irwi

Erdem, T., \& Swait, J. (2004). Brand Credibility, Brand Consideration, and Choice. Journal of Consumer Research, 31(1), 191-198. doi:10.1086/383434

Falk,R.F., \& Miller,N.B.(1992). A Primer for soft modelling ( $1^{\text {st }}$ ed.). Akron, Ohio 
Fatma, M., \& Rahman, Z. (2016). The CSRs influence on customer responses in Indian banking sector. Journal of Retailing and Consumer Services, 29, 49-57. doi: 10.1016/j.jretconser.2015.11.008

Fernando, S., Lawrence, S., Kelly, M., \& Arunachalam, M. (2015). CSR practices in Sri Lanka: an exploratory analysis. Social Responsibility Journal, 11(4), 868-892. doi: 10.1108/srj-08-2013-0101

Ferrell, O., Harrison, D. E., Ferrell, L., \& Hair, J. F. (2019). Business ethics, corporate social responsibility, and brand attitudes: An exploratory study. Journal of Business Research, 95, 491-501. doi: 10.1016/j.jbusres.2018.07.039

Fishbein, M. y Ajzen, I. (1975). Belief, attitude, intention, and behavior: An introduction to theory and research. Recuperado de https://people.umass.edu/aizen/f\&a1975.html

Fitch, H. G. (1976). Achieving Corporate Social Responsibility. Academy of Management Review, 1(1), 38-46. doi: 10.5465/amr.1976.4408754

Formánková, S., Trenz, O., Faldík, O., Kolomazník, J., \& Sládková, J. (2019). Millennials’ Awareness and Approach to Social Responsibility and Investment-Case Study of the Czech Republic. Sustainability, 11(2), 504. doi:10.3390/su11020504

Francis, J., Eccles, M. P., Johnston, M., Walker, A. E., Grimshaw, J. M., Foy, R., Kaner, E. F. S., Smith, L. and Bonetti, D. (2004). Constructing questionnaires based on the theory of planned behaviour: A manual for health services researchers. Newcastle upon Tyne, UK: Centre for Health Services Research, University of Newcastle upon Tyne.

Galahitiyawa, N.W.K. (2013).Outsourcing success : determining its critical managerial factors in the services industry, $\begin{array}{llll}P h . D & \text { Thesis, Retrieved from }\end{array}$ http://studentsrepo.um.edu.my/6115/1/nilakshi_CHA_090020_PHD_THESIS_Final.pdf

Garbarino, E., \& Johnson, M. (1999). The Different Roles of Satisfaction, Trust, and Commitment in Customer Relationships. Journal of Marketing, 63(2), 70-87. doi:10.2307/1251946

Giovannini, S., Xu, Y., \& Thomas, J. (2015). Luxury fashion consumption and Generation Y consumers. Journal of Fashion Marketing and Management: An International Journal, 19(1), 22-40. doi:10.1108/jfmm-08-2013-0096

Grandon, E. E. (2005). An Empirical Study of Factors That Influence E-Commerce Adoption/Non-Adoption in Small and Medium Sized Businesses. Journal of Internet Commerce, 4(4), 1-21. doi:10.1300/j179v04n04_01

Grant, I. J., \& Stephen, G. R. (2005). Buying behaviour of "tweenage" girls and key societal communicating factors influencing their purchasing of fashion clothing. Journal of Fashion Marketing and Management: An International Journal, 9(4), 450-467. doi:10.1108/13612020510620812

Graywood, M. (2018). How Brand Loyalty Differs Among the Generations. Retriever From: zgenerations/

Gupta, M., \& Hodges, N. (2012). Corporate social responsibility in the apparel industry. Journal of Fashion Marketing and Management: An International Journal, 16(2), 216-233. doi: 10.1108/13612021211222833

Han, H., Yu, J., Lee, K.-S., \& Baek, H. (2020). Impact of corporate social responsibilities on customer responses and brand choices. Journal of Travel \& Tourism Marketing, 37(3), 302-316. doi: 10.1080/10548408.2020.1746731

Hanna., K. Won-Moo., H, \& Junsang., Y. (2015). Corporate Brand Trust as a Mediator in the Relationship between Consumer Perception of CSR, Corporate Hypocrisy, and Corporate Reputation. Journal of sustainability, 7(4), 112 
Hair, J. F., Sarstedt, M., Ringle, C. M., \& Mena, J. A. (2011). An assessment of the use of partial least squares structural equation modeling in marketing research. Journal of the Academy of Marketing Science, 40(3), 414-433. doi: $10.1007 / \mathrm{s} 11747-011-0261-6$

Hair, J. F., Sarstedt, M., Pieper, T. M., \& Ringle, C. M. (2012). The Use of Partial Least Squares Structural Equation Modeling in Strategic Management Research: A Review of Past Practices and Recommendations for Future Applications. Long Range Planning, 45(5-6), 320-340. doi:10.1016/j.lrp.2012.09.008

Heald, M. (1970). The Social Responsibility of Business: Company and Community 1900-1960. Cleveland, OH. Case Western Reserve University Press.

He, Y., Chen, Q., \& Alden, D. L. (2015). Time will tell: managing post-purchase changes in brand attitude. Journal of the Academy of Marketing Science, 44(6), 791-805. doi: 10.1007/s11747-015-0444-7

Henseler, J., Ringle, C. M., \& Sinkovics, R. R. (2009). The use of partial least squares path modeling in international marketing. Advances in International Marketing New Challenges to International Marketing, 277-319. doi: 10.1108/s1474-7979(2009)0000020014

Hernández, A., \& Küster, I. (2012). Brand impact on purchasing intention. An approach in virtual social networks channels. Economics and Business Letters, 1(2).1-9.

Hoeffler, S., Bloom, P. N., \& Keller, K. L. (2010). Understanding Stakeholder Responses to Corporate Citizenship Initiatives: Managerial Guidelines and Research Directions. Journal of Public Policy \& Marketing, 29(1), 78-88. doi: 10.1509/jppm.29.1.78

Jorgensen, B. (2003). Baby Boomers, Generation X and Generation Y? Foresight, 5(4), 41- 49. doi:10.1108/14636680310494753

Jung, N. Y., \& Seock, Y.K. (2016). The impact of corporate reputation on brand attitude and purchase intention. Fashion and Textiles, 3(1). doi: 10.1186/s40691-016-0072-y

Karunanayaka,T \& Samarasinge, D. (2018). The Effect of Perceived Risk on the Purchase Intention of Alternative Fuel Vehicles. Sri Lankan Journal of Management,23(2),67-98.

Kim, H., Hur, W.-M., \& Yeo, J. (2015). Corporate Brand Trust as a Mediator in the Relationship between Consumer Perception of CSR, Corporate Hypocrisy, and Corporate Reputation. Sustainability, 7(4), 3683-3694. doi: $10.3390 / \mathrm{su} 7043683$

Kim, S.-H., Kim, M., Han, H.-S., \& Holland, S. (2016). The determinants of hospitality employees' pro-environmental behaviors: The moderating role of generational differences. International Journal of Hospitality Management, 52 , 56-67. doi: 10.1016/j.ijhm.2015.09.013

Ko, E., Taylor, C. R., Wagner, U., and Ji, H. (2008). Relationship among CEO image, corporate image and employment brand value in fashion industry. Journal of Global Academy of Marketing Science, 18 (4), 311-33

Kotler, P. (2000). Future Markets. Executive Excellence, 17(2), 6.

Laroche, M., Kim, C., \& Zhou, L. (1996). Brand familiarity and confidence as determinants of purchase intention: An empirical test in a multiple brand context. Journal of Business Research, 37(2), 115-120. doi:10.1016/01482963(96)00056-2 
Lazarevic, V. (2012). Encouraging brand loyalty in fickle generation Y consumers. Young Consumers, 13(1), 45-61. doi: $10.1108 / 17473611211203939$

Lee, M.D.P. (2008). A review of the theories of corporate social responsibility: Its evolutionary path and the road ahead. International Journal of Management Reviews, 10(1), 53-73. doi: 10.1111/j.1468-2370.2007.00226.x.

Lee,T., \& Cosenza, R. M. (2002). Profiling later aged female teens: Mall shopping behavior and clothing choice. Journal of Consumer Marketing, 19(5), 393-408. doi:10.1108/07363760210437623

Lee, D., \& Trail, G. T. (2012). Confirmatory analysis of the athletic team merchandise model. Measurement in Physical Education and Exercise Science, 16(2), 101-118. https://doi.org/10.1080/1091367X.2012.657555

Lenne, O. D., \& Vandenbosch, L. (2017). Media and sustainable apparel buying intention. Journal of Fashion Marketing and Management: An International Journal, 21(4), 483-498. doi:10.1108/jfmm-11-2016-0101

Leonidou, L. C., Kvasova, O., Leonidou, C. N., \& Chari, S. (2012). Business Unethicality as an Impediment to Consumer Trust: The Moderating Role of Demographic and Cultural Characteristics. Journal of Business Ethics, 112(3), 397-415. doi: 10.1007/s10551-012-1267-9

Levy, P. (1997). Virtual communities and information services: An overview. Vine, 27(5), 3-9. doi:10.1108/eb040660

Lin, W.-L., \& Yao, G. (2014). Predictive Validity. Encyclopedia of Quality of Life and Well-Being Research, 50205021. doi: 10.1007/978-94-007-0753-5_2241

Lin, M. Q., \& Lee, B. C. (2012). The influence of Website environment on brand loyalty: Brand trust and brand affect as mediators. International Journal of Electronic Business Management, 10(4). 308-321

Lissitsa, S., \& Kol, O. (2016). Generation X vs. Generation Y - A decade of online shopping. Journal of Retailing and Consumer Services, 31(2016), 304-312. doi:10.1016/j.jretconser.2016.04.015

Louton, D. L., \& J., D. B. A. (1993). Consumer behavior: concepts and applications. New York: McGraw-Hill.

Luffarelli, J., \& Awaysheh, A. (2018). The Impact of Indirect Corporate Social Performance Signals on Firm Value: Evidence from an Event Study. Corporate Social Responsibility and Environmental Management, 25(3), 295310. doi:10.1002/csr.1468

Ma Del Mar García De Los Salmones, Crespo, A. H., \& Bosque, I. R. (2005). Influence of Corporate Social Responsibility on Loyalty and Valuation of Services. Journal of Business Ethics, 61(4), 369-385. doi:10.1007/s10551-005-5841-2

Mattingly, C. (2012). Two virtue ethics and the anthropology of morality. Anthropological Theory, 12(2), 161-184. doi:10.1177/1463499612455284

Mendis,S.A \& Dharamasiri,A.S. (2018). The impact of multiple intelligences on individual work performance and the role of generation. Sri Lankan Journal of Management,24(1),1-29. Doi.org/10.33939/SLJM.2401.01.2019

M, G., \& Kk, S. R. (2018). Influence of Brand Attitude on Purchase Intention of Modular Kitchen in Chennai City. Journal of Accounting \& Marketing, 07(04). doi: 10.4172/2168-9601.1000300

Mitchell, A., \& Olson, J. (1981). Are Product Attribute Beliefs the Only Mediator of Advertising Effects on Brand Attitude? Journal of Marketing Research, 18(3), 318-332. doi:10.2307/3150973 
Mohr, L.A., and Webb, D.J. (2005). The effects of corporate social responsibility and price on consumer responses. Journal of Consumer Affairs, 39 (1), 121-14

Moura-Leite, R. C., \& Padgett, R. C. (2011). Historical background of corporate social responsibility. Social Responsibility Journal, 7(4), 528-539. doi: 10.1108/1747111111117511

Nadeem, W., Andreini, D., Salo, J., \& Laukkanen, T. (2015). Engaging consumers online through websites and social media: A gender study of Italian Generation Y clothing consumers. International Journal of Information Management, 35(4), 432-442. doi: 10.1016/j.ijinfomgt.2015.04.008

Naser, V., \& Nikhashemi, S. (2017). Generation Y consumers' buying behaviour in fashion apparel industry: A moderation analysis. Journal of Fashion Marketing and Management: An International Journal, 21(4), 523-543. doi:10.1108/jfmm-01-2017-0002

Neal, W. D. (2000). Three's not the magic number: when measuring loyalty satisfactorily, don't measure CS. Marketing News, 19.

Nigbur, D., Lyons, E., \& Uzzell, D. (2010). Attitudes, norms, identity and environmental behaviour: Using an expanded theory of planned behaviour to predict participation in a kerbside recycling programme. British Journal of Social Psychology, 49(2), 259-284. doi:10.1348/014466609x449395

Noble, S. M., Haytko, D. L., \& Phillips, J. (2009). What drives college-age Generation Y consumers? Journal of Business Research, 62(6), 617-628. doi: 10.1016/j.jbusres.2008.01.020

Nunnally, J. C. (1978). Psychometric theory: 2nd ed. New York: McGraw-Hill.

Parment, A. (2011). Generation Y vs. Baby Boomers: Shopping behavior, buyer involvement and implications for retailing. Journal of Retailing and Consumer Services, 20(2), 189-199. doi:10.1016/j.jretconser.2012.12.001

Patterson,C.K.(2007). Generational Diversity - The Impact of Generational Diversity in the Workplace. Journal of Corporate Real Estate ,13(2):98-108

Pivato, S., Misani, N., \& Tencati, A. (2007). The impact of corporate social responsibility on consumer trust: the case of organic food. Business Ethics: A European Review, 17(1), 3-12. doi: 10.1111/j.1467-8608.2008.00515.x

Prakash, G., and Pathak, P. (2017). Intention to buy eco-friendly packaged products among young consumers of India: a study on developing nation. Journal of Cleaner Production, 14 (10), 385-393.

Pomering, A., \& Dolnicar, S. (2009). Assessing the Prerequisite of Successful CSR Implementation: Are Consumers Aware of CSR Initiatives? Journal of Business Ethics, 85(S2), 285-301. doi: 10.1007/s10551-008-9729-9.

Posavac, S. S., Sanbonmatsu, D. M., \& Fazio, R. H. (1997). Considering the best choice: Effects of the salience and accessibility of alternatives on attitude-decision consistency. Journal of Personality and Social Psychology, 72(2), 253-261. https://doi.org/10.1037/0022-3514.72.2.253

Richter, N. F., Cepeda, G., Roldán, J. L., \& Ringle, C. M. (2015). European management research using Partial Least Squares Structural Equation Modeling (PLS-SEM). European Management Journal, 33(1), 1-3. doi: 10.1016/j.emj.2014.12.001

Ranaweera,U.C.M., \& Dharamasiri,A.S. (2016). Generation Y \& their job performncw. Sri Lankan Journal of Management,21(1),39-82. 
Reynaldo, R. F., Alshammari, F., Alquwez, N., Alicante, J. G., Obaid, K. B., . . . Silang, J. P. (2017). Factors Influencing Arab Nursing Students Attitudes toward Climate Change and Environmental Sustainability and their Inclusion in Nursing Curricula. Public Health Nursing, 35(6), 598-605. doi:10.1111/phn.12516

Romani, L., Mahadevan, J., \& Primecz, H. (2016). Critical Cross-Cultural Management: Outline and Emerging Contributions. International Studies of Management \& Organization, 48(4), 403-418. doi:10.1080/00208825.2018.1504473

Salehzadeh, R., \& Pool, J. K. (2016). Brand Attitude and Perceived Value and Purchase Intention toward Global Luxury Brands. Journal of International Consumer Marketing, 29(2), 74-82. doi: $10.1080 / 08961530.2016 .1236311$

Saunders, M., Lewis, P., \& Thornhill, A. (2009). Research methods for business students. 5th Ed. New York: Pearson.

Schivinski, B., \& Dabrowski, D. (2014). The effect of social media communication on consumer perceptions of brands. Journal of Marketing Communications, 22(2), 189-214. doi:10.1080/13527266.2013.871323

Sekaran, S.H., \& Bougie,R. (2010). Research Methods for Business- A Skill Building Approach. $4^{\text {th }}$ edition. New Delhi. John Wiley \& Sons Inc.

Sen, S., \& Bhattacharya, C. (2001). Does Doing Good Always Lead to Doing Better? Consumer Reactions to Corporate Social Responsibility. Journal of Marketing Research, 38(2), 225-243. doi: 10.1509/jmkr.38.2.225.18838

Severo, E., Guimarães, J., Dellarmelin, M., \& Ribeiro, R. (2019). The Influence of Social Networks on Environmental Awareness and the Social Responsibility of Generations. Brazilian Business Review, 16(5), 500-518. doi: 10.15728/bbr.2019.16.5.5

Shamma,H.M., \& Hassan, S.S. (2011). Integrating Product and Corporate Brand Equity into Total Brand Equity Measurement. International Journal of Marketing Studies, 3(1), 11-20.

Shen, B., Wang, Y., Lo, C. K., \& Shum, M. (2012). The impact of ethical fashion on consumer purchase behavior. Journal of Fashion Marketing and Management: An International Journal, 16(2), 234-245. doi:10.1108/13612021211222842

Shepard, D. S., \& Zeckhauser, R. J. (1984). Survival versus Consumption. Management Science, 30(4), 423-439. doi:10.1287/mnsc.30.4.423

Shim, S., Eastlick, M. A., Lotz, S. L., \& Warrington, P. (2001). An online prepurchase intentions model. Journal of Retailing, 77(3), 397-416. doi:10.1016/s0022-4359(01)00051-3

Sicilia, M., Ruiz, S., \& Reynolds, N. (2006). Attitude Formation Online - how the Consumers need for Cognition Affects the Relationship between Attitude towards the Website and Attitude towards the Brand. International Journal of Market Research, 48(2), 139-154. doi: 10.1177/147078530604800204

Singh, J., Maria Del Mar Garcia De Los Salmones Sanchez, \& Bosque, I. R. D. (2007). Understanding Corporate Social Responsibility and Product Perceptions in Consumer Markets: A Cross-cultural Evaluation. Journal of Business Ethics, 80(3), 597-611. doi: 10.1007/s10551-007-9457

Smola, K. W., \& Sutton, C. D. (2002). Generational differences: Revisiting generational work values for the new millennium. Journal of Organizational Behavior, 23(4), 363-382. doi:10.1002/job.147 
Spears, N., \& Singh, S. N. (2004). Measuring Attitude toward the Brand and Purchase Intentions. Journal of Current Issues \& Research in Advertising, 26(2), 53-66. doi: 10.1080/10641734.2004.10505164

Sprinkle, G. B., \& Maines, L. A. (2010). The benefits and costs of corporate social responsibility. Business Horizons, 53(5), 445-453. doi: 10.1016/j.bushor.2010.05.006

Strauss, W., \& Howe, N. (1992). Generations the history of Americas future, 1584 to 2069. New York, NY: Quill.

Sullivan, P., \& Heitmeyer, J. (2008). Looking at Gen Y shopping preferences and intentions: exploring the role of experience and apparel involvement. International Journal of Consumer Studies, 32(3), 285-295. doi: 10.1111/j.1470-6431.2008.00680.x

Tajfel, H. \& Turner, J.C. (1986) .The Social Identity Theory of Intergroup Behavior. In: Worchel, S. and Austin, W.G., Eds., Psychology of Intergroup Relation, Hall Publishers, Chicago, 7-24.

Terry, D. J., \& Hogg, M. A. (1996). Group norms and the attitude-behavior relationship: A role for group identification. Personality and Social Psychology Bulletin, $22(8), \quad 776-$ https://doi.org/10.1177/0146167296228002

Urip, S. (2010). CSR strategies: Corporate social responsibility for a competitive edge in emerging markets. Singapore: Wiley.

Vaaland, T. I., Heide, M., \& Grønhaug, K. (2008). Corporate social responsibility: investigating theory and research in the marketing context. European Journal of Marketing, 42(9/10), 927-953. doi: 10.1108/03090560810891082

Valaei, N., \& Nikhashemi, S. (2017). Generation Y consumers' buying behaviour in fashion apparel industry: A moderation analysis. Journal of Fashion Marketing and Management: An International Journal, 21(4), 523-543. doi:10.1108/jfmm-01-2017-0002

Vila, N., \& Kuster, I. (2011). Consumer feelings and behaviours towards well designed websites. Information \& Management, 48(4-5), 166-177. doi:10.1016/j.im.2011.04.003

Weerasinghe, T.D., \& Jayawardana, A.K.L.(2019). Flex-Work and Work-Life Balance: Effect Role Conflicts and Work-Life Support Organizational Culture, Sri Lankan Journal of Management,24(2),49-76. doi:10.33939/SLJM.24.02.03.2019

Werther, W. B., \& Chandler, D. (2005). Strategic corporate social responsibility as global brand insurance. Business Horizons, 48(4), 317-324. doi:10.1016/j.bushor.2004.11.009

Wetzels, Odekerken-Schröder, \& Oppen, V. (2009). Using PLS Path Modeling for Assessing Hierarchical Construct Models: Guidelines and Empirical Illustration. MIS Quarterly, 33(1), 177. doi: 10.2307/20650284

Wongpitch, S., Minakan, N., Powpaka, S., \& Laohavichien, T. (2016). Effect of corporate social responsibility motives on purchase intention model: An extension. Kasetsart Journal of Social Sciences, 37(1), 30-37. doi: 10.1016/j.kjss.2016.01.010

Wu, S.-I., \& Wang, W.-H. (2014). Impact of CSR Perception on Brand Image, Brand Attitude and Buying Willingness: A Study of a Global Café. International Journal of Marketing Studies, 6(6). doi: 10.5539/ijms.v6n6p43

Yazdanpanah, M., \& Forouzani, M. (2015). Application of the Theory of Planned Behaviour to predict Iranian student's intention to purchase organic food. Journal of Cleaner Production, 107, 342-352. doi:10.1016/j.jclepro.2015.02.071 
Yoo, B., Donthu, N., \& Lee, S. (2000). An Examination of Selected Marketing Mix Elements and Brand Equity. Journal of the Academy of Marketing Science, 28(2), 195-211. doi: 10.1177/0092070300282002

Zhao, X., Lynch, J. G., \& Chen, Q. (2010). Reconsidering Baron and Kenny: Myths and Truths about Mediation Analysis. Journal of Consumer Research, 37(2), 197-206. doi: 10.1086/651257 